Human Rights Education 



\title{
HUMAN RIGHTS EDUCATION
}

Theory, Research, Praxis

\author{
Edited by \\ Monisha Bajaj \\ Afterword by \\ Nancy Flowers
}

\author{
$\overline{\text { PENN }}$ \\ UNIVERSITY OF PENNSYLVANIA PRESS \\ PHILADELPHIA
}


Copyright (c) 2017 University of Pennsylvania Press

All rights reserved. Except for brief quotations used for purposes of review or scholarly citation, none of this book may be reproduced in any form by any means without written permission from the publisher.

\author{
Published by \\ University of Pennsylvania Press \\ Philadelphia, Pennsylvania 19104-4112 \\ www.upenn.edu/pennpress \\ Printed in the United States of America \\ on acid-free paper
}

$\begin{array}{llllllllll}10 & 9 & 8 & 7 & 6 & 5 & 4 & 3 & 2 & 1\end{array}$

Library of Congress Cataloging-in-Publication Data

Names: Bajaj, Monisha, editor. | Flowers, Nancy, 1940- writer of afterword.

Title: Human rights education : theory, research, praxis / edited by

Monisha Bajaj ; afterword by Nancy Flowers.

Other titles: Human rights education (University of Pennsylvania)

Description: 1st edition. | Philadelphia : University of Pennsylvania Press,

[2017] | Includes bibliographical references and index.

Identifiers: LCCN 2016053346 | ISBN 9780812249026 (hardcover : alk.

paper)

Subjects: LCSH: Human rights-Study and teaching.

Classification: LCC JC571 .H8668 2017 | DDC 323.071—dc23

LC record available at https://lccn.loc.gov/2016053346 